\title{
First record of Eastern Cloud Forest Rat Nephelomys nimbosus (Rodentia: Cricetidae) for Colombia
}

\author{
Sebastian Bautista Plazas ${ }^{1,2 *}$, Abelardo Rodríguez Bolaños² and Ronald Castellanos Florez ${ }^{2}$ \\ ${ }^{1}$ Laboratorio Ecología de Bosques Tropicales y Primatologia, Universidad de los Andes, Carrera 1 No 18A 12. Bogotá 111711, \\ Colombia. Email: sebastianbautista386@gmail.com (SB). \\ ${ }^{2}$ Laboratorio Biodiversidad de Alta Montaña, Universidad Distrital Francisco José de Caldas, Carrera 4 No 26B54. Bogotá 111611, \\ Colombia. Email: mountainresearch@gmail.com (AR), kabuz2013@gmail.com (RC). \\ ${ }^{*}$ Corresponding author
}

Currently, four species of Nephelomys (N. childi, N. maculiventer, N. meridiensis and N. pectoralis) are known from Colombia. Here we present the first records of a fifth species, the rare Eastern Cloud Forest rat $N$. nimbosus, previously considered endemic to Ecuador and so far recorded only at five localities in the forests of the Eastern Cordillera. Four individuals of N. nimbosus were captured with Sherman traps at National Natural Park Cueva de los Guacharos in Huila Department, southern Colombia. Individuals were captured at two locations, a subandine primary forest at 2,000 $\mathrm{m}$ and at small cave 'Cueva de los Guacharos', at 1,900 m. Individuals were identified as N. nimbosus according to the following characteristics: ventral patche of self - colored white hairs in the gular region, ventral pelage ochraceous yellow with a golden tone, medium head-body size between 122 to $140 \mathrm{~mm}$, incisive foramina between 4.6 and $5.1 \mathrm{~mm}$ with lateral margins rounded, posterolateral palatal pits small to big shallow and simple, hourglass shaped interorbital region, with supraorbital margins rounded or squared and a thin and delicate face. These new records increase the known species distribution by 760 kilometers to the north and present the first record of the species in Colombia. This first record of $N$. nimbosus for Colombia potentially extends the species distribution for northeastern Ecuadorian Cordillera and southern Colombian Cordillera. These results show the need to continue with the collection of specimens in poorly known species as $N$. nimbosus and in poorly known areas in Colombia, such as montane forests.

Actualmente, Colombia presenta cuatro especies del genero Nephelomys (N. childi, N. maculiventer, N. meridiensis y N. pectoralis), aquí presentamos una quinta especie, la poco conocida rata de bosques nublados Nephelomys nimbosus, anteriormente considerada endemica de Ecuador y hasta ahora reportada para cinco localidades en bosques de la Cordillera Oriental. Cuatro individuos de N. nimbosus fueron capturados mediante trampas Sherman en el Parque Nacional Natural Cueva de los Guacharos, en el departamento de Huila, Colombia. Los individuos fueron encontrados en dos localidades, un bosque primario subandino a 2,000 m de altitud, y en una pequeña caverna "Cueva de los Guacharos", a 1,900 m de altitud. Los individuos pudieron ser identificados como N. nimbosus de acuerdo con las siguientes características: Parche ventral con pelos de color blanco en la región gular, pelaje ventral color amarillo ocre con un tono dorado, tamaño mediano, con una longitud entre la cabeza y el cuerpo de 122 to $140 \mathrm{~mm}$; el foramen incisivo corto entre 4.6 y $5.1 \mathrm{~mm}$ con márgenes laterales redondeados, fosas palatales posterolaterales pequeñas a grandes, superficiales y simples; región interorbital en forma de reloj de arena, con márgenes supraorbitales redondeados o cuadrados, un rostro delgado y delicado. Estos nuevos ejemplares permiten aumentar la distribución de la especie por 760 kilómetros y presentar el primer registro de la especie para Colombia. Este primer registro de N. nimbosus para Colombia, extiende la distribución de la especie para el norte de la cordillera oriental de Ecuador y el sur de Colombia. Los resultados muestran la necesidad de continuar con la colecta de especímenes en los bosques montanos de áreas poco conocidas de Colombia.

Key words: Andes; montane forest; small non flying mammals; Thomasomyini.

(C) 2018 Asociación Mexicana de Mastozoología, www.mastozoologiamexicana.org

\section{Introduction}

Cloud forest rats belonging to genus Nephelomys (Cricetidae: Sigmodontinae) distribute in the Andes (900 to $3000 \mathrm{~m}$ ); they can be found in wooded paramo, montane cloud and elfin forest ecosystems (Percequillo 2003, 2015). Species of genus Nephelomys are present in South America from Colombia to Bolivia, including costal Venezuela, extending to the Cordilleras of Panama and Costa Rica in Central America (Percequillo 2003, 2015; Prado and Pecrequillo 2013). Four of the thirteen species of the genus, N. childi, N. maculiventer, N. pectoralis and N. meridiensis are known from Colombia (Percequillo 2003, 2015; Solari et al. 2013; Ramirez-Chavez et al. 2016).

Historically the species N. nimbosus (Anthony 1926) was considered endemic to Ecuador. It was known from five localities along the eastern slope of the Andes Cordillera, specifically two locations in the Napo Province (Baeza and Chaco Oyacachi River) and two in the Tungurahua Province (San Antonio, San Francisco; Percequillo 2003, 2015). Later, a new locality record at southeastern Ecuador (Tapichalaca, Zamora Chinchipe Province) was reported (Brito et al. 2015; Figure 1). Given the scarcity of records, the natural history of N. nimbosus is poorly known. Here we present the Colombian first record for $N$. nimbosus.

\section{Materials and methods}

Individuals were captured between February and August of 2014 as part of the first inventory of small non flying mammals for the Natural National Park Cueva de los Guacharos (PNNCG) located in the department of Huila, Colombia 


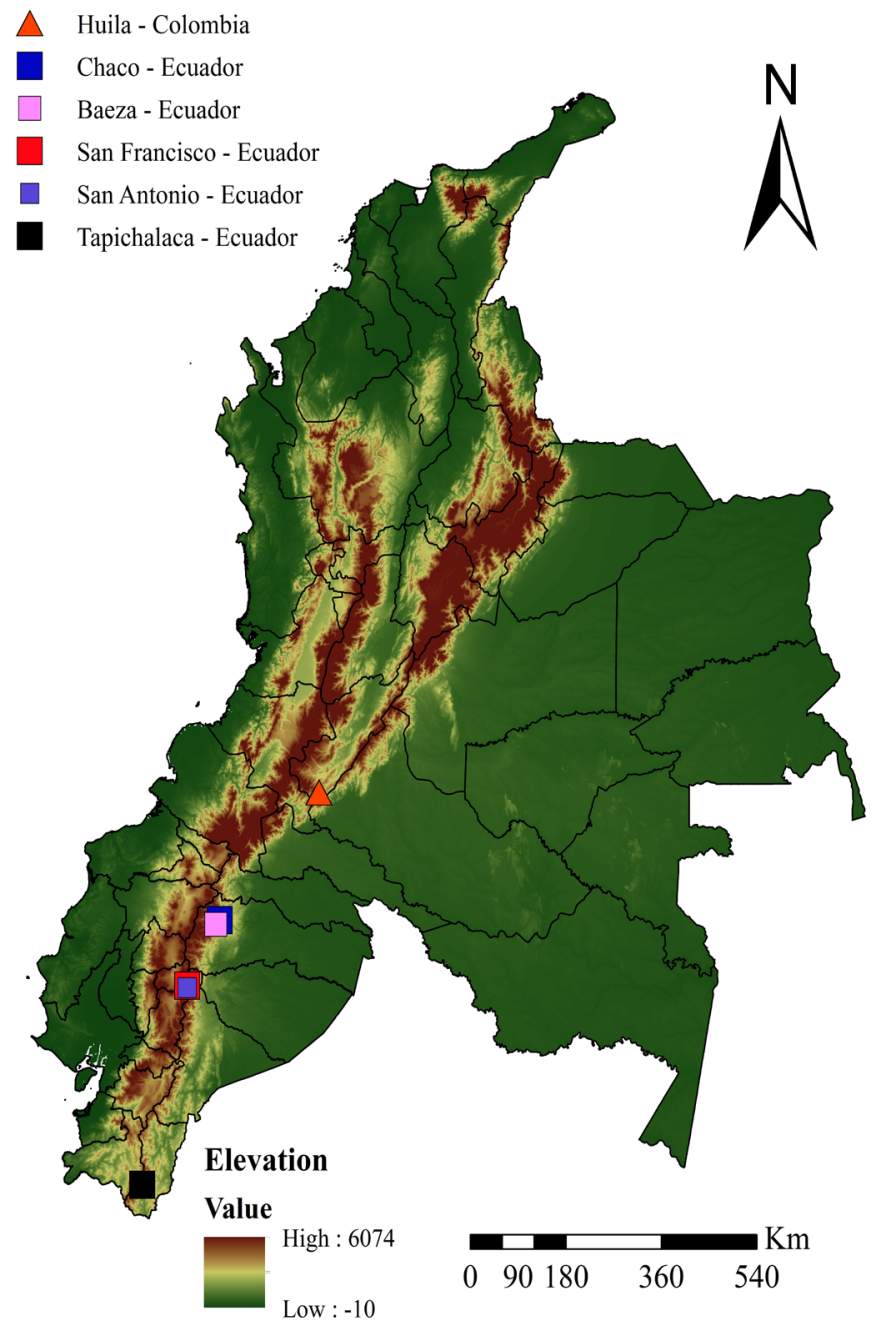

Figure 1. Recording localities of Nephelomys nimbosus in Ecuador and the new one in Colombia at Huila department.

$\left(1^{\circ} 36.14^{\prime} \mathrm{N},-76^{\circ} 8.13^{\prime} \mathrm{W}\right)$. Capture survey consist in linear transects of Sherman traps placed on the ground, a total of 100 traps were active for 150 days, totalizing a trapping effort of 1,5000 traps night (Bautista et al. 2014). N. nimbosus individuals were captured at two of the five sampling localities. The first one was a subandine primary forest at $2000 \mathrm{~m}$; this location presents a high canopy with lianas and palms; some of the most abundant species were plants of the genus Wettinia, Hyeronima, Alchornea, Miconia, and Inga (Prada and Stevenson 2010). The second trapping locality was 'Cueva de los Guacharos' at 1900 m, a small cave with no vegetation where nocturnal frugivore birds known as oilbirds (Steatornis caripensis) build their nests and spend most of the daylight. The accumulation of Oilbird seed wastes on the bottom of the cave (e. g., Prestoea acuminate, Geonoma sp, Dacryodes sp, and Oenocarpus bataua) serves as a food resource for small non-flying mammals, like $N$. nimbosus and N. childi (Bautista et al. 2014).

The N. nimbosus specimens were deposited in the mammal collection of the Universidad Distrital Francisco Jose de Caldas (MUD) in Bogota, Colombia. Analyzed specimens (MUD 877; MUD 883; MUD 884; MUD 893) were compared with the holotype of $N$. nimbosus (American Museum of
Natural History, AMNH 67337; Anthony 1926; Percequillo 2003), and a specimen of this species from south eastern Ecuador deposited in the Ecuadorian Museum of Natural Sciences (DMMECN 1083; Brito et al. 2015). Also, specimens were compared with individuals of N. childi (MUD 876; MUD 876; MUD 880; MUD 887; MUD 889). Body and cranial measures were taken with a gauge \pm 0.1 following the definitions of Voss (1988) and Patton et al. (2000).

\section{Results}

Four individuals from a total of 198 of the first inventory of small non flying mammals of PNNCG were identified as belonging to N. nimbosus using the description and key provided in Anthony (1926) and Percequillo (2003, 2015). Some co-occurring species were Marmosops parvidens, Marmosops caucae, Heteromys anomalus, Melanomys caliginosus, Chilomys instans, Neacomys tenuipes, Rhipidomys latimanus, Microryzomys minutus, Tramsandinomys talamancae and Nephelomys childi, most of them typical of montane forest.

Captured individuals present the following characteristics that separates them from those of $N$. auriventer and $N$. childi (Figure 2). Ventral patch of self - colored white hairs in the gular region (not present in N. auriventer), ventral pelage ochraceous yellow with a golden tone ( $N$. childi presents ventral pelage grayish or whitish washed with gray), medium body size between 122 and $140 \mathrm{~mm}(\mathrm{~N}$. auriventer is larger, measuring between 140 and $173 \mathrm{~mm}$ ), incisive foramina short range: 4.6 to $5.1 \mathrm{~mm}$ with lateral margins rounded $(N$. auriventer has long incisive foramina range: 5.6 to $6.7 \mathrm{~mm}$ with teardrop shape), posterolateral palatal pits small to big shallow and simple ( $N$. childi presents posterolateral palatal pits complex small numerous and deep), interorbital region hourglass shaped, with supraorbital margins rounded or squared ( $N$. auriventer has an interorbital region with strongly beaded supraorbital margins, which diverge posteriorly) and a thin and delicate face (N. nimbosus has a robust and strong face; Anthony 1926; Percequillo 2003, 2015). No comparison were made with $N$. pectoralis because of its distinctive large and wide white ventral patches and its numerous and deep posterolateral pits placed in deep palatal fossae (Allen 1912; Weksler et al. 2006). Most of cranial and body measures of the four individuals are within the known range for the species (Percequillo 2003, 2015; Weksler et al. 2006; Brito et al. 2015; Table 1). This new record of $N$. nimbosus expands the known distribution of the species $760 \mathrm{~km}$ towards north, and constitutes the first record of the species for Colombia.

\section{Discussion and conclusions}

Colombian sigmodontines have recently suffered taxonomic changes, as well as improvements in their know distribution. Hence, the species number from Colombia has increased from 66 in 2013 (Solari et al. 2013) to 75 in 2016 (Ramirez-Chavez et al. 2016). The new records of N. nimbosus of the present study and of N. meridiensis mentioned by Percequillo (2015; previously identified as Nephelomys 


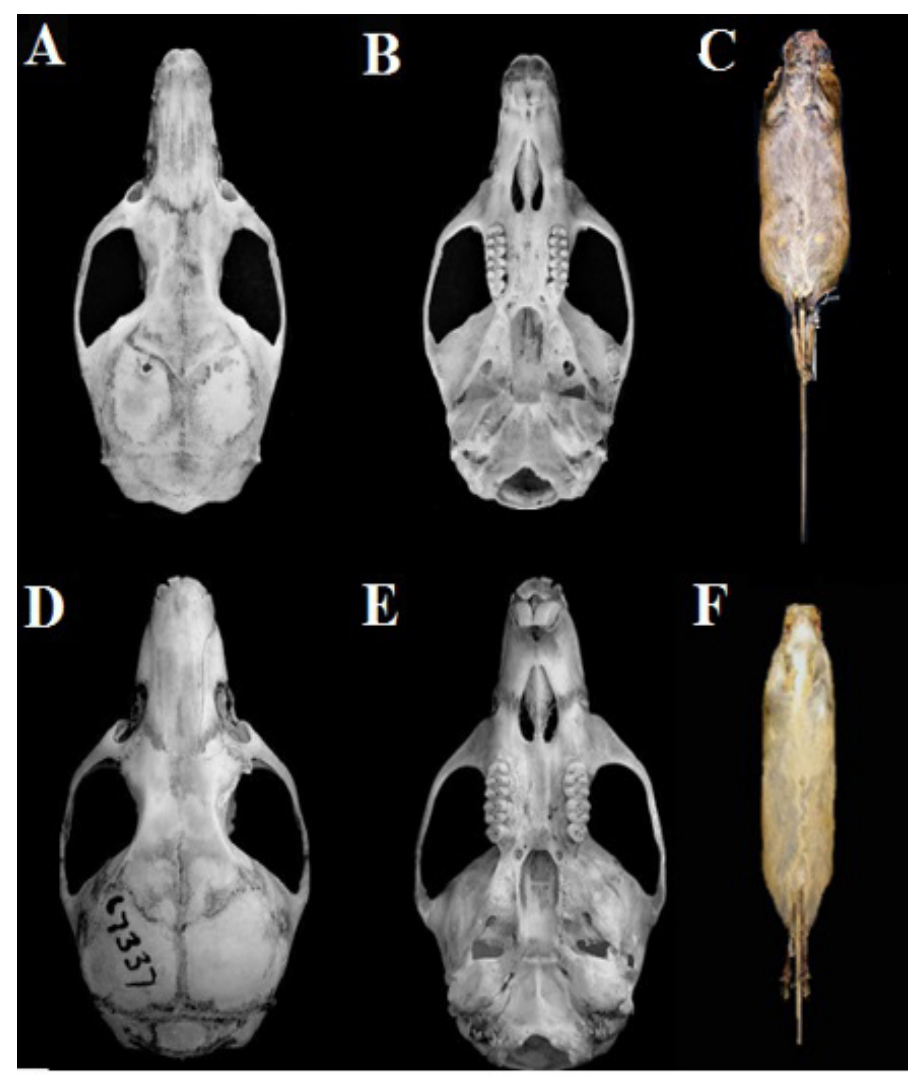

Figure 2. Dorsal (A) and ventral view (B) of the skull and (C) skin of an adult Colombian female of Nephelomys nimbosus (MUD 883). Dorsal (D) and ventral view (E) of the skull and (F) skin of the holotype of Nephelomys nimbosus (AMNH 67337). sp. by Solari et al. 2013 and Percequillo 2003), increase the number of species of genus from three to five for Colombia and contributes to the constant changes of the Colombian sigmodontines species list.

The discovery of $N$. nimbosus in Colombia is important due to the apparently restricted distribution of the species that was previously known only from five localities in Ecuador (Percequillo 2003, 2015; Prado and Pecrequillo 2013; Brito et al. 2015). The potential presence of the species extends to the northern Ecuadorian Cordillera, the Colombian Cordillera massif, and to the southern part of the Colombian eastern Cordillera. Although the Andes montane forests have been catalogued as hotspots of mammalian diversity and endemism (Myers et al. 2000; Ceballos and Ehrlich 2006), it is important to increase the sampling effort for small non-flying mammals in this poorly known region where deforestation rate is increasing alarmingly (Armenteras et al. 2011). The limited number of known individuals of $N$. nimbosus makes of it a rare species with a poorly known distribution (Percequillo 2003, 2015; Prado and Pecrequillo 2013). For instance, in the present study the species had an abundance of four out of a total 198 small mammals captured, with a 15,000 traps night sampling effort, during a five months continuous sampling period (Bautista et al. 2014). We suggest increasing the amount of studies in the montane forest near the borderline between Colombia and Ecuador, where the species potentially could

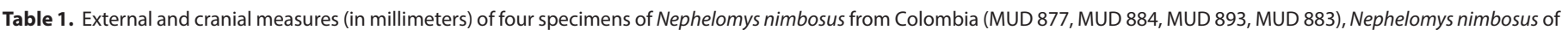

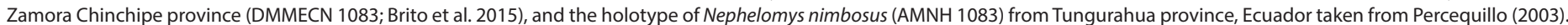

\begin{tabular}{|c|c|c|c|c|c|c|}
\hline \multirow[b]{2}{*}{ Measures (mm) } & \multicolumn{4}{|c|}{ Colombia } & \multicolumn{2}{|c|}{ Ecuador } \\
\hline & MUD 877 & MUD 884 & MUD 893 & MUD 883 & $\begin{array}{c}\text { AMNH } 67337 \\
\text { (Holotype) }\end{array}$ & $\begin{array}{c}\text { DMMECN } \\
1083\end{array}$ \\
\hline Total length & 284 & 292 & 302 & 242 & 300 & 289 \\
\hline Tail length & 129 & 149 & 153 & 116 & 160 & 147 \\
\hline Head and Body length & 155 & 143 & 149 & 126 & 140 & 142 \\
\hline Hindfoot length & 30.8 & 32.0 & 31.6 & 30.7 & 34.0 & 33.0 \\
\hline Ear length & 20.9 & 18.2 & 17.7 & 16.6 & - & 19.0 \\
\hline Weight (grams) & 74.9 & 73.7 & 57.4 & 42.3 & - & 84.0 \\
\hline Condylo insicive length & 33.02 & 30.73 & 30.37 & 27.86 & 32.04 & 30.50 \\
\hline Superior molar series length & 6.46 & 5.54 & 5.38 & 5.61 & 5.57 & 5.50 \\
\hline Diastema length & 10.35 & 8.69 & 9.30 & 7.77 & 9.48 & 9.10 \\
\hline Incisive foramina length & 5.80 & 5.41 & 4.83 & 4.36 & 5.12 & 4.30 \\
\hline Occipitonasal length & 36.61 & 34.25 & 33.65 & 30.81 & 35.33 & 34.10 \\
\hline Molar 1 width & 1.78 & 1.72 & 1.62 & 1.78 & 1.64 & - \\
\hline Nasal length & 14.32 & 12.38 & 13.91 & 12.69 & 13.13 & - \\
\hline Incisive foramina width & 3.35 & 2.33 & 2.39 & 1.96 & 2.82 & - \\
\hline Zygomatic plate width & 3.57 & 2.94 & 3.09 & 2.65 & 3.81 & 3.80 \\
\hline Palatal bridge width & 3.48 & 3.16 & 3.98 & 3.05 & - & - \\
\hline Inter orbital lesser width & 4.94 & 5.11 & 5.85 & 4.85 & 5.79 & 5.40 \\
\hline Zygomatic width & 18.59 & 17.49 & 16.52 & - & 17.75 & 18.40 \\
\hline Rostral length & 8.00 & 9.12 & 9.92 & 7.38 & - & 11.50 \\
\hline Cranial width & 14.39 & 14.29 & 13.77 & 13.32 & 15.30 & 14.30 \\
\hline Cranial height & 10.21 & 9.60 & 9.93 & 9.73 & 10.80 & 10.20 \\
\hline
\end{tabular}


be found. Due to these facts it is essential to increase studies of the genus Nephelomys, with the purpose of gathering information about species geographical distribution and ecology, which in turn would contribute useful material to clarify species limits and their phylogenetic relationships.

\section{Acknowledgments}

Special thanks to Alexandre Reis Percequillo for his help on the identification of collected individuals. Two anonymous reviewers provided valuable comments on an earlier version of this paper. To all the staff of Cueva de los Guacharos National Natural Park for their support and hospitality.

\section{References}

Allen, J. A. 1912. Mammals from western Colombia. Bulletin of the American Museum of Natural History 31:71-95.

Anthony, H. E. 1926. Preliminary report on Ecuadorean mammals. No.7. American Museum Novitates 240:1-6.

Armenteras, D., N. Rodriguez, J. Retana, and M. Morales. 2011. Understanding deforestation in montane and lowland forest of the Colombian Andes. Regional Environmental Change 11:693-705.

Bautista, S., A. Rodriguez, and P. R. Stevenson. 2014. Diversidad de pequeños mamíferos no voladores en el Parque Nacional Natural Cueva de los guacharos (Huila, Colombia). Tesis (Pregrado) Universidad de los Andes. Bogotá, Colombia.

BRito, J., N. TINoco, AND F. SornozA. 2015. New distributional record of endemic Nephelomys nimbosus mouse (Rodentia: Cricetidae) in southeastern Ecuador. Therya 6:667-674.

Ceballos, G., AND P. EHRLICH. 2006. Global mammal distributions, biodiversity hotspots, and conservation. PNAS 103:374-379.

Myers, N., R. A. Mittermeier, C.G. Mittermeier, G.A. Da FonseCA, ANd J. KENT. 2000. Byodiversity hotspots for conservation priorities. Nature 403:853-858.

Patton, J. L., M. N. Silva, AND J. R. Malcolm. 2000. Mammals of the Rio Juruá and the evolutionary and ecological diversification of Amazonia. Bulletin of the American Museum of Natural History 244:1-306.

Percequillo, A. R. 2003. Sistemática de Oryzomys Baird, 1858: definição dos grupos de espécie e revisão taxonómica do grupo albigularis (Rodentia, Sigmodontinae). These (Doutorado) Universidade de São Paulo. São Paulo, Brasil.

Percequillo, A. R. 2015. Genus Nephelomys Weksler, Percequillo, y Voss, 2006. PAGINAS, in Mammals of South America. Volume 2, Rodents (Patton, J. L., U. F. J. Pardiñas, and G. D'Elía, eds.). The University of Chicago Press. Chicago, U. S. A.

Prada, C. M., and P. R. Stevenson. 2010. Composición vegetal asociada a gradientes ambientales en bosques tropicales de montaña (Parque Nacional Cueva de Los Guacharos, Huila-Colombia). Tesis (Pregrado) Universidad de los Andes. Bogotá, Colombia.

Prado, J. R., and A. R. Percequillo. 2013. Geographic distribution of the genera of the Tribe Oryzomyini (Rodentia: Cricetidae: Sigmodontinae) in South America: patterns of distribution and diversity. Arquivos de Zoología 44:1-120.

Ramirez, H. E., A. F. Suarez, and J. F. Gonzalez. 2016. Cambios recientes a la lista de mamíferos de Colombia. Mammalogy notes 3:1-9.
Solari, S., Y. Muñoz, J. V. Mahecha, T. R. Defler, H. Chavez, and F. Truillo. 2013. Riqueza, endemismo y conservación de los mamíferos de Colombia. Mastozoologia Neotropical 20:301-365.

Tinoco, N. O. 2015. Caracterización molecular, morfológica y morfometrica del complejo Nephelomys albigularis Tomes, 1860 (Rodentia: Cricetidae), y su distribución en el Ecuador. Tesis (Pregrado). Pontificia Universidad Católica de Ecuador. Quito, Ecuador.

Voss, R. S. 1988. Systematics and ecology of Ichthyomyine rodents (Muroidea): patterns of morphological evolution in a small adaptive radiation. Bulletin of the American Museum of Natural History 188:259-493.

Weksler, M., A. R. Percequillo, and R. S. Voss. 2006. Ten New Genera of Oryzomyine Rodents (Cricetidae: Sigmodontinae). American Museum Novitates 3537:1-29.

\section{Associated editor: Rafael Avila}

Submitted: August 2, 2016; Reviewed: Septiembre 17, 2016;

Accepted: January 17, 2018; Published on line: January 26, 2018. 